\title{
MENINGKATKAN KOMPETENSI PEDAGOGI GURU MELALUI LESSON STUDY MENUJU MUTU PEMBELAJARAN GURU
}

\author{
Syafruddin \\ SMA Teladan Kota Metro \\ Email: syafruddinmetro@gmail.com
}

\begin{abstract}
Abstrak
Artikel ini bertujuan mengkaji strategi peningkatan kompetensi pedagogik guru melalui suatu mekanisme in-service training yang lebih berfokus pada upaya pemberdayaan guru sesuai dengan kapasitas serta permasalahan yang dihadapi oleh masing-masing guru dikelas, untuk meningkatkan mutu pembelajaran guru melalui lesson study. Lesson study adalah suatu model pembinaan profesi pendidik melalui pengkajian pembelajaran kolaboratif dan berkelanjutan berlandaskan prinsip-prinsip kolegalitas dan mutual learning untuk membangun komunitas belajar. Lesson study dipilih dan diimplementasikan dalam rangka peningkatan kompetensi pedagogi guru karena lesson study merupakan suatu cara efektif untuk meningkatkan kualitas belajar dan mengajar di kelas. Lesson study dilaksanakan dalam bentuk siklus plando-see (reflection). Melalui lesson study diharapkan terjadi peningkatan kompetensi pedagogik dan, peningkatan mutu pembelajaran.
\end{abstract}

Kata kunci: lesson study, kompetensi pedagogik, mutu pembelajaran

\begin{abstract}
This article aims to examine strategies for improving pedagogical competence through in service training that is more focused on the empowerment of teachers in accordance with the capacity and the problems faced by teachers in the classroom, to improve the quality of teacher learning through lesson study. lesson study is a model of professional development of educators through collaborative learning and continuous assessment based on collegiality and mutual learning. to build a learning community. lesson study selected and implemented in order to improve the pedagogical competence as an effective way to improve the quality of learning and teaching in class. Lesson study carried out in the form of a cycle plan-do-see. through lesson study expected to increase pedagogical competence and increase the quality of learning.
\end{abstract}

Keywords : lesson study, competence pedagogical,quality of teaching 


\section{PENDAHULUAN}

Masalah mutu pendidikan merupakan salah satu isu sentral dalam pendidikan nasional,terutama berkaitan dengan rendahnya mutu pendidikan pada seatiap jenjang dan satuan pendidikan,terutama pada jenjang pendidikan dasar dan menengah. Menyadari hal tersebut, pemerintah telah melakukan berbagai upaya untuk meningkatkan mutu pendidikan nasional antara lain melalui berbagai pelatihan dan peningkatan kompetensi guru, pengadaan buku dan media pembelajaran, perbaikan sarana dan prasarana pendidikan,serta peningkatan mutu manejemen sekolah.Meskipun demikian, berbagai indikator mutu pendidikan mengindikasikan bahwa berbagai upaya tersebut belum menunjukkan hasil yang memuaskan,dan belum menunjukkan peningkatan yang berarti.

Kondisi tersebut mengundang berbagai pertanyaan dari berbagai pihak,baik dari kalangan masyarakat umum maupun dari kalangan ahli pendidikan dan para guru: "apa yang salah dalam penyelenggaraan pendidikan kita?'Menurut pengamat dan analisis ada tiga faktor yang menyebabkan mutu pendidikan tidak mengalami peningkatan secara merata. Adapun ketiga faktor tersebut adalah sebagai berikut :

Pertama, kebijakan penyelenggaraan pendidikan nasional menggunakan pendekatan education production function atau input -output analisis yang tidak dilaksanakan secara konskuen. Pendekatan ini beranggapan apabila input pendidikan dipenuhi seperti, alat-alat pendidikan, sarana dan prasarana maka mutu pendidikan otomatis akan terjadi, dalam kenyataannya mutu pendidikan tidak terjadi ,karena pendekatan education production function berpusat pada input pendidikan dan kurang memperhatikan pada proses pendidikan.Padahal, proses pendidikan sangat menentukan mutu pendidikan.

Kedua, Penyelenggaraan pendidikan nasional yang sentralistik, telah mengakibatkan sekolah sebagai penyelenggara sangat tergantung kepada keputusan birokrasi,yang jalur 
sangat panjang dan kadang-kadang kebijakan yang dikeluarkan tidak sesuai dengan di lapangan.

Ketiga, peran serta masyarakat, khususnya orang tua siswa dalam penyelenggaran pendidikan sangat minim. Partisipasi masyarakat selama ini pada umumnya lebih bersifat dukungan input( dana) bukan pada proses pendidikan.

Rendahnya mutu pendidikan yang tercermin pada rendahnya mutu SDM disebabkan oleh kurangnya perhatian guru terhadap kualitas proses pembelajaran. Umumnya pembelajaran yang berlangsung di kelas dalam bentuk komunikasi satu arah, guru lebih banyak berceramah dan siswa mendengarkan. Guru beranggapan bahwa tugasnya hanya mentransfer pengetahuan yang dimilikinya kepada siswa dengan target tersampaikannya topik-topik yang tertuang dalam kurikulum kepada siswa. Guru pada umumnya kurang memberi inspirasi kepada siswa untuk berkreasi, berargumentasi secara ilmiah, dan tidak membimbing para siswanya untuk menuju hidup mandiri. Pembelajaran yang disajikan guru kurang menantang siswa untuk mengembangkan kemampuan dan keterampilan berpikir. Oleh karena itu, perbaikan mutu pendidikan harus diawali dengan perbaikan proses pembelajaran. Paradigma yang hanya mementingkan hasil tes atau ujian harus segera diubah menjadi penekanan pada proses pembelajaran, sedangkan hasil ujian atau tes merupakan dampak dari proses pembelajaran yang benar dan berkualitas.

Dalam rangka meningkatkan mutu pendidikan, pemerintah dan DPR telah mengesahkan UU RI No. 14 Th. 2005 tentang guru dan dosen. Undangundang tersebut menuntut penyesuaian peyelenggaraan pendidikan dan pembinaan guru agar guru menjadi profesional. Guru dituntut untuk menuhi standar minimal seorang profesional yaitu memiliki kualifikasi akademik S1 atau D4 (Pasal 9), dan memiliki sertifikat pendidik (Pasal 10). Agar seorang guru menjadi profesional, guru harus memiliki kompetensi pedagogi, kompetensi profesional, kompetensi kepribadian, dan kompetensi sosial. 
Kompetensi pedagogi, yaitu kemampuan mengelola pembelajaran, meliputi (1) memahami karakteristik peserta didik dari aspek fisik, sosial, moral, kultural, dan intelektual, (2) memahami latar belakang keluarga dan masyarakat peserta didik dan kebutuhan belajar dalam konteks kebhinekaan budaya, (3) memahami gaya belajar dan kesulitan belajar peserta didik, (4) memfasilitasi pengembangan potensi peserta didik, (5) menguasai teori dan prinsip-prinsip belajar serta pembelajaran yang mendidik, (6) mengembangkan kurikulum yang mendorong keterlibatan peserta didik dalam pembelajaran, (7) merancang pembelajaran yang mendidik; (8) melaksanakan pembelajaran yang mendidik, dan (9) mengevaluasi proses dan hasil belajar.

Kompetensi profesional, yaitu kemampuan menguasai materi pembelajaran secara luas dan mendalam yang memungkinkannya membimbing peserta didik memenuhi standar kompetensi. Kompetensi profesional meliputi (1) menguasai substansi bidang studi dan metodologi keilmuannya, (2) menguasai struktur dan materi kurikulum bidang studi, (3) menguasai dan memanfaatkan teknologi informasi dan komunikasi dalam pembelajaran, mengorganisasikan materi kurikulum bidang studi, dan (5) meningkatkan kualitas pembelajaran melalui penelitian tindakan kelas.

Kompetensi kepribadian, yaitu memiliki kepribadian yang mantap, stabil, dewasa, dan berwibawa menjadi teladan bagi peserta didik dan berakhlak mulia. Kompetensi kepribadian mencakup menampilkan diri sebagai pribadi yang mantap, stabil, dewasa, arif, dan berwibawa, (2) menampilkan diri sebagai pribadi yang berakhlak mulai dan sebagai telaan bagi peserta didik dan mayarakat, (3) mengevaluasi kinerja sendiri, dan mengembangkan diri secara berkelanjutan.

Kompetensi sosial, yaitu kemampuan berkomunikasi secara efektif denga peserta didik, sesama pendidik, dan masyarakat sekitar. Dengan kompetensi sosial ini, guru diharapkan dapat (1) berkomunikasi 
secara efektif dan empatik dengan peserta didik, orang tua peserta didik, sesama pendidik, tenaga kependidikan, dan masyarakat, (2) berkontribusi terhadap pengembangan pendidikan di sekolah dan masyarakat,

berkontribusi terhadap pengembangan pendidikan di tingkat lokal, regional, nasional, dan global, dan

Memanfaatkan teknologi informasi dan komunikasi (ICT) untuk beromunikasi dan pengembangan diri.

Pemerintah telah melakukan berbagai upaya peningkatan mutu guru melalui penataran dan atau pelatihan. Namun upaya pemerintah ini kurang memberikan dampak yang signifikan terhadap peningkatan mutu guru. Kurang berhasilnya upaya peningkatan mutu guru melalui penataran dan atau pelatihan disebabkan oleh dua hal pokok, yaitu (1) penataran dan pelatihan yang dilakukan tidak berbasis pada permasalahan nyata di kelas, dan (2) hasil penataran dan pelatihan hanya menjadi pengetahuan saja, tidak diterapkan secara berkelanjutan di dalam kelas. Setelah selesai penataran dan/pelatihan, guru kembali mengajar dengan pola atau strategi sebelumnya.

Dalam upaya mengatasi kelemahan model penataran dan/atau pelatihan konvensional yang kurang memberi tekanan pada pasca pelatihan, maka lesson study merupakan salah strategi yang dipandang efektif untuk meningkatkan mutu guru. Lesson study merupakan model atau strategi in-service training yang lebih berfokus pada upaya pemberdayaan guru sesuai dengan kapasitas serta permasalahan yang dihadapi oleh masing-masing guru. Sehubungan dengan hal itu, maka artikel ini akan membahas apa, mengapa, dan bagaimana lesson study.

\section{METODE}

Metode yang digunakan dalam penelitian ini adalah studi kepustakaan dan teknik yang digunakan adalah teknik simak catat. Studi kepustakaan adalah teknik pengumpulan data dengan mengadakan studi telaah terhadap buku-buku, litertur-literatur, catatan-catatan, dan laporan-laporan serta sumber tertulis lain yang 
berhubungan dengan masalah yang akan dipecahkan (Nazir. 1988).

Teknik simak catat adalah teknik pengumpulan data dengan cara menggunakan buku-buku, literatur ataupun bahan pustaka, kemudian mencatat atau mengutip pendapat para ahli yang ada di dalam sumber tersebut untuk memperkuat landasan teori dalam penelitian. Teknik simak catat ini menggunakan buku-buku, literatur, atau bahan pustaka yang relevan dengan penelitian yang dilakukan, biasanya dapat ditemukan di perpustakaan maupun di tempat penulis melakukan penelitian.

\section{HASIL DAN PEMBAHASAN}

\section{Tahapan-Tahapan Lesson Study}

Berkenaan dengan tahapantahapan dalamlesson study ini, dijumpai beberapa pendapat. Menurut Wikipedia (2007) bahwa lesson study dilakukan melalui empat tahapan dengan menggunakan konsep PlanDo-Check-Act (PDCA). Sementara itu, Slamet Mulyana mengemukakan tiga tahapan dalam lesson study, yaitu : (1) Perencanaan (Plan); (2) Pelaksanaan (Do) dan (3) Refleksi (See). Sedangkan Bill Cerbin dan Bryan Kopp dari University of Wisconsin mengetengahkan enam tahapan dalam Lesson Study, yaitu:

- Form a Team: membentuk tim sebanyak 3-6 orang yang terdiri guru yang bersangkutan dan pihak-pihak lain yang kompeten serta memilki kepentingan dengan lesson study.

- Develop Student Learning Goals: anggota tim memdiskusikan apa yang akan dibelajarkan kepada siswa sebagai hasil dari Lesson Study.

- Plan the Research Lesson: guru-guru mendesain pembelajaran guna mencapai tujuan belajar dan mengantisipasi bagaimana para siswa akan merespons.

- Gather Evidence of Student Learning: salah seorang guru tim melaksanakan pembelajaran, sementara yang lainnya melakukan pengamatan, mengumpulkan buktibukti dari pembelajaran siswa.

- Analyze Evidence of Learning: tim mendiskusikan 
Syafruddin - Meningkatkan Kompetensi Pedagogi...

hasil dan menilai kemajuan

dalam pencapaian tujuan belajar siswa

- Repeat the Process: kelompok merevisi pembelajaran, mengulang tahapan-tahapan mulai dari tahapan ke-2 sampai dengan tahapan ke-5 sebagaimana dikemukakan di atas, dan tim melakukan sharing atas temuan-temuan yang ada. Untuk lebih jelasnya, dengan merujuk pada pemikiran Slamet Mulyana (2007) dan konsep Plan-Do-CheckAct (PDCA), di bawah ini akan diuraikan secara ringkas tentang empat tahapan dalam penyelengggaraan Lesson Study

\section{Tahapan Perencanaan (Plan)}

Dalam tahap perencanaan,para guru yang tergabung dalam.lesson study

berkolaborasi untuk menyusun RPP yang mencerminkan pembelajaran yang berpusat pada siswa. Perencanaan diawali dengan kegiatan menganalisis kebutuhan dan permasalahan yang dihadapi dalam pembelajaran, seperti tentang: kompetensi dasar, cara membelajarkan siswa, mensiasati kekurangan fasilitas dan sarana belajar, dan sebagainya, sehingga dapat ketahui berbagai kondisi nyata yang akan digunakan untuk kepentingan pembelajaran. Selanjutnya, secara bersama-sama pula dicarikan solusi untuk memecahkan segala permasalahan ditemukan. Kesimpulan dari hasil analisis kebutuhan dan permasalahan menjadi bagian yang harus dipertimbangkan dalam penyusunan RPP, sehingga RPP menjadisebuah perencanaan yang benar-benar sangat matang, yang didalamnya sanggup mengantisipasi segala kemungkinan yang akan terjadi selama pelaksanaan pembelajaran berlangsung, baik pada tahap awal, tahap inti sampai dengan tahap akhir pembelajaran.

\section{Tahapan Pelaksanaan}

Pada tahapan yang kedua, terdapat dua kegiatan utama yaitu: (1) kegiatan pelaksanaan pembelajaran yang dilakukan oleh salah seorang guru yang disepakati atau atas permintaan 
sendiri untuk mempraktikkan RPP yang telah disusun bersama, dan (2) kegiatan pengamatan atau observasi yang dilakukan oleh anggota atau komunitas lesson study yang lainnya (baca: guru, kepala sekolah, atau pengawas sekolah, atau undangan lainnya yang bertindak sebagai pengamat.Beberapa hal yang harus diperhatikan dalam tahapan pelaksanaan, diantaranya:

\section{- Guru} melaksanakan pembelajaran sesuai dengan RPP yang telah disusun bersama.

- Siswa diupayakan dapat menjalani proses pembelajaran dalam setting yang wajar dan natural, tidak dalam keadaan under pressure yang disebabkan adanya program Lesson Study.

- Selama kegiatan pembelajaran berlangsung, pengamat tidak diperbolehkan mengganggu jalannya kegiatan pembelajaran dan mengganggu konsentrasi guru maupun siswa.

- Pengamat melakukan pengamatan secara teliti terhadap interaksi siswa-siswa, siswa-bahan ajar, siswa-guru, siswa-lingkungan lainnya, dengan menggunakan instrumen pengamatan yang telah disiapkan sebelumnya dan disusun bersama-sama.

- Pengamat harus dapat belajar dari pembelajaran yang berlangsung dan bukan untuk mengevalusi guru.

- Pengamat dapat melakukan perekaman melalui video camera atau photo digital untuk keperluan dokumentasi dan bahan analisis lebih lanjut dan kegiatan perekaman tidak mengganggu jalannya proses pembelajaran.

- Pengamat melakukan pencatatan tentang perilaku belajar siswa selama pembelajaran berlangsung, misalnya tentang komentar atau diskusi siswa dan diusahakan dapat mencantumkan nama siswa yang bersangkutan, terjadinya proses konstruksi pemahaman siswa melalui aktivitas belajar siswa. Catatan dibuat 
Syafruddin - Meningkatkan Kompetensi Pedagogi...

berdasarkan pedoman dan urutan pengalaman belajar siswa yang tercantum dalam RPP.

\section{Tahapan Refleksi}

Tahapan ketiga merupakan tahapan yang sangat penting karena upaya perbaikan proses pembelajaran selanjutnya akan bergantung dari ketajaman analisis para perserta berdasarkan pengamatan terhadap pelaksanaan pembelajaran yang telah dilaksanakan. Kegiatan refleksi dilakukan dalam bentuk diskusi yang diikuti seluruh peserta Lesson Study yang dipandu oleh kepala sekolah atau peserta lainnya yang ditunjuk. Diskusi dimulai dari penyampaian kesan-kesan guru yang telah mempraktikkan pembelajaran, dengan menyampaikan komentar atau kesan umum maupun kesan khusus atas proses pembelajaran yang dilakukannya, misalnya mengenai kesulitan dan permasalahan yang dirasakan dalam menjalankan RPP yang telah disusun. Selanjutnya, semua pengamat menyampaikan tanggapan atau saran secara bijak terhadap proses pembelajaran yang telah dilaksanakan (bukan terhadap guru yang bersangkutan). Dalam menyampaikan

saran-saranya pengamat harus didukung oleh buktibukti yang diperoleh dari hasil pengamatan, tidak berdasarkan opininya. Berbagai pembicaraan yang berkembang dalam diskusi dapat dijadikan umpan balik bagi seluruh peserta untuk kepentingan perbaikan atau peningkatan proses pembelajaran. Oleh karena itu, sebaiknya seluruh peserta pun memiliki catatan-catatan pembicaraan yang berlangsung dalam diskusi.

\section{Tahapan Tindak Lanjut}

Dari hasil refleksi dapat diperoleh sejumlah pengetahuan baru atau keputusan penting guna perbaikan dan peningkatan proses pembelajaran, baik pada tataran individual, maupun menajerial. Pada tataran individual, berbagai temuan dan masukan berharga yang disampaikan pada saat diskusi dalam tahapan refleksi tentunya menjadi modal bagi para guru, baik yang bertindak sebagai pengajar maupun observer untuk mengembangkan proses pembelajaran ke arah lebih baik. Pada tataran manajerial, dengan pelibatan langsung kepala sekolah sebagai peserta lesson 
study tentunya kepala sekolah akan memperoleh sejumlah masukan yang berharga bagi kepentingan pengembangan manajemen pendidikan di sekolahnya secara keseluruhan. Kalau selama ini kepala sekolah banyak disibukkan dengan hal-hal di luar pendidikan, dengan keterlibatannya secara langsung dalam lesson study, maka dia akan lebih dapat memahami apa yang sesungguhnya dialami oleh guru dan siswanya dalam proses pembelajaran, sehingga diharapkan kepala sekolah dapat semakin lebih fokus lagi untuk mewujudkan dirinya sebagai pemimpin pendidikan di sekolah.

\section{Keutamaan Lesson Study}

Lesson study adalah suatu model pembinaan profesi pendidik melalui pengkajian pembelajaran kolaboratif dan berkelanjutan berlandaskan prinsip-prinsip kolegalitas dan mutual learning untuk membangun komunitas belajar (Hendayana, dkk: 2006). Lesson study merupakan pendekatan yang komprehensif menuju pembelajaran yang profesional serta menopang guru menjadi pembelajar sepanjang hayat dalam upaya mengembangkan dan meningkatkan kualitas pembelajaran di kelas. Lesson study bukan merupakan suatu metode atau strategi pembelajaran tetapi kegiatan lesson study dapat menerapkan berbagai metode atau strategi pembelajaran yang sesuai dengan situasi, kondisi, dan permasalahan yang dihadapi guru.

Lesson study dapat diartikan sebagai program in-service training guru yang dilakukan secara kolaboratif dan berkelanjutan. Lesson study dilakukan di dalam kelas dengan tujuan untuk memahami siswa dengan lebih baik dan dilakukan secara bersama-sama dengan guru lain (Rahayu, 2005). Lesson study merupakan strategi pengembangan profesionalisme guru. Melalui aktivitas lesson study, pembelajaran dikembangkan secara bersama-sama dengan menentukan salah satu guru untuk melaksanakan pembelajaran tersebut, sedangkan guru lainnya mengamati aktivitas belajar siswa selama pembelajaran berlangsung. Pada akhir kegiatan, guru berkumpul kembali dan melakukan diskusi tentang pembelajaran yang telah berlangsung, merevisi dan menyusun program pembelajaran berikutnya 
berdasarkan hasil diskusi. Lesson study memberi dorongan kepada guru untuk menjadi pembelajar sepanjang hayat tentang bagaimana mengembangkan dan memperbaiki pembelajaran di kelas. Melalui lesson study guru akan terbantu dalam hal (1) mengembangkan pemikiran kritis tentang belajar dan mengajar di kelas, (2) merancang program pembelajaran (RPP) yang berkualitas, mengobsevasi bagaimana siswa berpikir dan belajar serta melakukan tindakan yang cocok,

Mendiskusikan dan merefleksikan aktivitas pembelajaran, dan (5) mengidentifikasi pengetahuan dan keterampilan yang dibutuhkan untuk meningkatkna praktek pembelajaran

Dalam lesson study para guru bekerjasama dalam hal memformulasi tujuan pembelajaran dan pengembangan jangka panjang, (2) secara kolaboratif merancang suatu "research lesson", (3) melaksanakan pembelajaran dengan menugaskan seorang guru untuk mengajar dan yang anggota tim yang lain melakukan observasi untuk mengumpulkan data tentang kejadian belajar di kelas, (4) mendiskusikan kejadian-kejadian belajar yang telah diobservasi selama proses pembelajaran, menggunakan informasi itu untuk memperbaiki kualitas pembelajaran, dan (5) mengimplementasikan program pembelajaran yang telah direvisi pada kelas lain, dan jika perlu mengkaji dan memperbaiki kembali program pembelajaran tersebut. Lesson study dapat digambarkan sebagai suatu siklus kegiatan kelompok guru yang bekerja bersama dalam menentukan tujuan pembelajaran, melakukan research lesson dan secara berkolaborasi mengamati, mendiskusikan dan memperbaiki pembelajaran tersebut (Lewis, 2002). Siklus lesson study digambarkan Seperti pada gambar 1.

Berdasarkan hal tersebut, dapat disintesiskan bahwa lesson study pada hakikatnya merupakan pendekatan yang komprehensif menuju pembelajaran yang profesional serta mensuport guru menjadi pembelajar sepanjang hayat dalam upaya mengembangkan dan meningkatkan kualitas pembelajaran di kelas. Secara diagram, gambaran umum tentang lesson study dapat dilukiskan seperti pada gambar 2. 


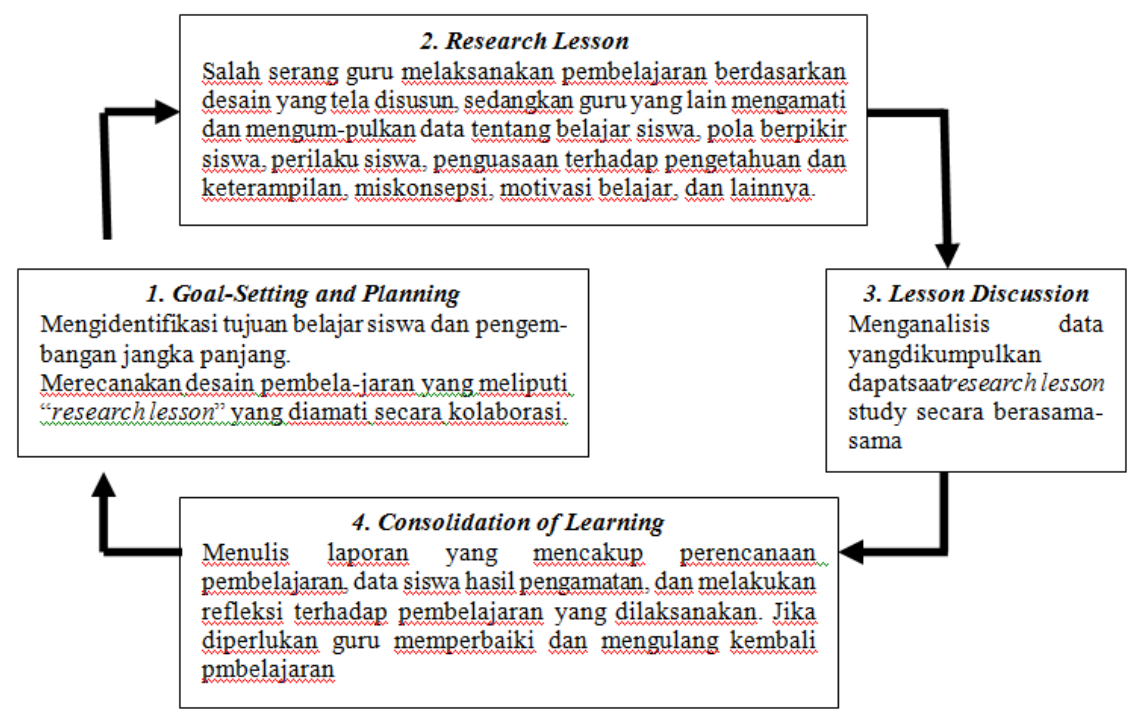

Gambar 1. Siklus lesson study

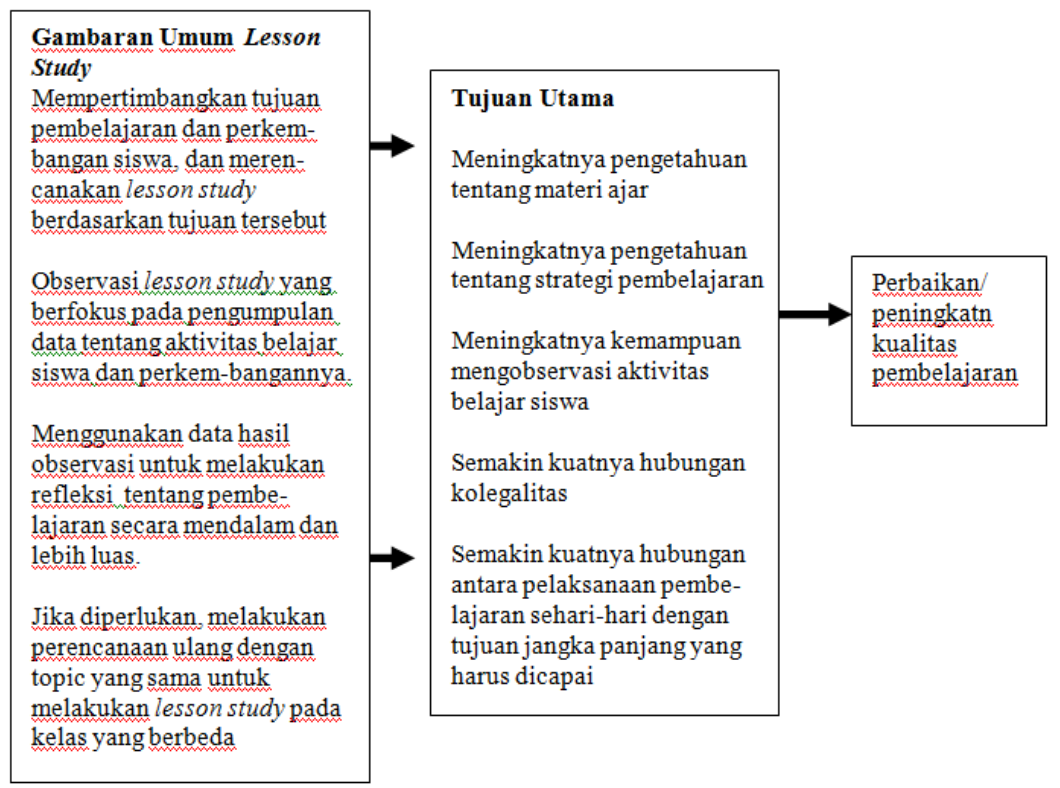

Gambar 2 : Gambaran Umum Lesson Study (Hendayana,2006:39)

\section{Urgensi Lesson Study bagi peningkatan kompetensi pedagogi}

\section{Kompetensi Pedagogik}

guru karena empat alasan utama.

Lesson study dipilih dan Pertama, lesson study

diimplementasikan dalam rangka merupakan suatu cara efektif untuk 
meningkatkan kualitas belajar dan mengajar di kelas, dengan alasan (1) pengembangan lesson study dilakukan dan didasarkan pada hasil "sharing" pengetahuan profesional yang berlandaskan pada praktek dan hasil pembelajaran yang dilaksanakan para guru; (2) penekanan mendasar suatu lesson study adalah para siswa memiliki kualitas belajar yang baik; (3) tujuan pembelajaran digunakan sebagai fokus dan titik perhatian utama dalam pembelajaran di kelas; (4) berdasarkan pengalaman real di kelas, lesson study mampu menjadi landasan bagi pengembangan pembelajaran; dan (5) lesson study akan menempatkan peran para guru sebagai peneliti pembelajaran (Lewis, 2002).

Kedua, lesson study yang didesain dengan baik akan menghasilkan guru yang prefesional dan inovatif. Dengan melaksanakan lesson study para guru dapat (1) menentukan tujuan, satuan pelajaran (unit lesson), dan mata pelajaran yang efektif, (2) mengkaji dan meningkatkan pelajaran yang bermanfaat bagi siswa, (3) memperdalam pengetahuan tentang mata pelajaran yang disajikan para guru, (4) menentukan tujuan jangka panjang yang akan dicapai para siswa, (5) merencanakan pelajaran secara kolaboratif, (6) mengkaji secara teliti belajar dan perilaku siswa, (7) mengembangkan pengetahuan tentang pembelajaran yang dapat diandalkan, (8) melakukan refleksi terhadap pengajaran yang dilaksnakannya berdasarkan pandangan siswa dan koleganya ( Muchtar, 2006).

Ketiga, lesson study memiliki beberapa manfaat, antara lain: (1) mereduksi isolasi guru, (2) membantu guru untuk mengobservasi dan memberi kritik terhadap suatu pembelajaran, (3) memperdalam pemahaman guru terhadap isi (content) dan sekuen atau urutan materi pelajaran, (4) memberi wahana bagi guru untuk memfokuskan pada bantuan belajar bagi siswa, dan (5) meningkatkan kolaborasi dan respek guru antara satu dengan lainnya.

Keempat, lesson study memiliki beberapa keistimewaan, antara lain (1) lesson study mendorong para guru untuk belajar sepanjang hayat dalam upaya meningkatkan profesionalismenya, (2) lesson study 
dirancang secara kolaboratif dalam kurun waktu tertentu melalui suatu studi yang intensif terhadap materi ajar, karakteristik siswa, dan strategi pembelajaran, (3) lesson study menawarkan suatu proses dalam menumbuhkembangkan motivasi belajar siswa, (4) lesson study memberi dorongan untuk memberi fokus pada berpikir siswa melalui observasi kelas, (5) lesson study memicu terjadinya refleksi berbasis pada data observasi di kelas, dan (6) lesson study memunculkan perspektif baru tentang belajar dan mengajar.

Interaksi yang dikembangkan dalam suatu diskusi akan sangat berperan dalam proses berkembangnya pengetahuan pada diri seseorang. Lesson study sebagai suatu kegiatan yang yang diawali dengan pengembangan perencanaan pembelajaran secara kolaboratif, pelaksanaan proses pembelajaran yang dilangsungkan secara terbuka dengan melibatkan sejumlah observer, dan ditindaklanjuti dengan diskusi dan refleksi pasca pembelajaran, merupakan suatu kegitan yang sangat potensial untuk menciptakan suasana interaksi yang kondusif antar berbagai pihak yaitu guru, dosen, kepala sekolah, pengawas, komite sekolah, dan lain sebagainya. Melalui interaksi yang terjadi dalam berbagai tahapan kegiatan lesson study akan sangat dimungkinkan terjadinya tukar gagasan (sharing) pengetahuan. Dengan berkembangnya pengetahuan secara konstruktif berbasis pada data observasi yang objektif di kelas, masing-masing pihak akan memperoleh input dan umpan balik, dan juga akan sangat mungkin dapat memunculkan berbagai inovasi pembelajaran.

Persiapan lesson study dapat melibatkan banyak pihak misalnya, kelompok guru bidang studi dalam satu sekolah, kelompok guru lintas bidang dalam satu sekolah, kelompok guru sebidang dalam MGMP, dan sebagainya. Dengan demikian rencana pembelajaran yang disusun bersama diharapkan kualitasnya akan lebih baik dibandingkan dengan rencana pembelajarn yang disusun secara individual. Keterlibatan berbagai pihak dalam pengembangan program pembelajaran sangat memungkinkan terjadinya sharing pendapat, 
pengalaman, dan pengetahuan secara konstruktif.

Persiapan lesson study meliputi beberapa kegiatan, antara lain indentifikasi masalah pembelajaran, analisis masalah pembelajaran dari aspek materi ajar, serta alternatif strategi pembelajaran yang mungkin diterapkan, dan penyusunan rencana pembelajaran. Pada tahap ini, para guru berkolaborasi melakukan analisis terhadap pembelajaran yang biasa dilakukan untuk topik tertentu, mendiskusikan cara-cara yang mungkin untuk mengatasi masalah pembelajaran, memilih alternatif yang terbaik yang akan diuji-cobakan, menyiapkan teaching material serta merancang strategi pembelajaran yang inovatif untuk topik terpilih. Karena fokus diskusi meliputi materi ajar, teaching material, strategi pembelajaran yang inovatif, pihakpihak yang terlibat dalam diskusi akan berkontribusi sesuai dengan kemampuan dan pengalamannya. Dengan demikian, berarti terjadi sharing pengalaman dan pengetahuan secara konstruktif, sehingga wawasannya tentang masalah pembelajaran semakin berkembang.
Ada beberapa persyaratan yang perlu disiapkan agar lesson study dapat dilaksanakan dengan baik, yakni (1) diperlukan semangat introspeksi diri terhadap apa yang sudah dilakukan selama ini dalam melaksanakan proses pembelajaran. Pertanyaan-pertanyaan seperti apakah saya sudah melakukan tugas mendidik dengan baik, apakah saya sudah dapat meningkatkan motivasi belajar siswa, apakah saya telah mengidentifikasi dan mengenali miskonsepsi siswa, apakah saya sudah mengembangkan keterampilan berpikir siswa, apakah saya sudah dapat meminimalkan kesulitan belajar siswa, adalah pertanyaan-pertanyaan yang harus dijawab secara jujur. Jawaban-jawaban tersebut akan memberi dorongan untuk mencari cara gunba menyempurnakan kekurangankekurangan atas jawaban tersebut; (2) diperlukan keberanian membuka diri untuk dapat menerima kritik dan saran dari pihak lain dalam upaya meningkatkan kualitas diri; diperlukan keberanian untuk mengakui kesalahan diri sendiri; (4) diperlukan keberanian untuk mengakui dan menggunakan ide orang lain yang lebih baik; (5) diperlukan keberanian 
untuk memberi kritik dan masukan secara objektif kepada orang lain; dan (6) diperlukan komitmen pengelola sekolah, MGMP, Dinas Pendidikan, Perguruan Tinggi, Komite Sekolah, dan pemerhati pendidikan (Joharmawan, 2006:2).

\section{PENUTUP}

\section{Kesimpulan}

Berdasarkan hasil penelitian dan pembahasan, dapat disimpulkan bahwa terdapat hubungan yang signifikan antara persepsi siswa terhadap penerapan model pembelajaran kooperatif tipe tutor sebaya dengan prestasi belajar fisika pada pokok bahasan getaran dan gelombang siswa kelas VIII MTs Umbul Sari Buay Pemuka Bangsa Raja Tahun Pembelajaran 2014/2015.

\section{Saran}

$$
\begin{aligned}
& \text { Berdasarkan temuan-temuan } \\
& \text { selama penelitian, diberikan saran } \\
& \text { sebagai perbaikan di masa mendatang. } \\
& \text { Dari hasil penelitian memperlihatkan } \\
& \text { bahwa prestasi belajar siswa tinggi } \\
& \text { jika persepsi siswa terhadap penerapan } \\
& \text { model pembelajaran koperatif tipe } \\
& \text { tutor sebaya tinggi, dan sebaliknya } \\
& \text { prestasi belajar siswa rendah jika }
\end{aligned}
$$

persepsi siswa terhadap penerapan model pembelajaran koperatif tipe tutor sebaya rendah. Sudah seharusnya sebelum melaksanakan pembelajaran, hendaknya memperhatikan aspek psikologis siswa seperti kesiapan untuk belajar, rasa ingin tahu, serta menggunakan model pembelajaran yang lebih variatif dan menarik. Hal ini diharapkan akan membuat persepsi siswa baik, sehingga terjadi peningkatan terhadap prestasi belajarnya.

\section{DAFTAR PUSTAKA}

Hendayana,Sumar dkk. 2006. Lesson Study. Suatu Strategi untuk Meningkatkan Keprofesionalan Pendidik. UPI Press.Lewis, Catherine C. 2002. Lesson Study: A Handbook of Teacher-Led Instructional Change. Philadelphia, PA: Research for Better Schools. Inc.

Muchtar, A. Karim. 2006. Apa, Mengapa, dan Bagaimana Lesson Study. Makalah disajikan pada Pelatihan Lesson Study Untuk Mengingkatkan Kompetensi Guru Berprestasi dan Pengurus MGMP Bidang MIPA dan Bidang Studi lainnya Jenjang SMP/MTS dan SMA?MA Wilayah Indonesia Timur.

Nazir, (1988), Metode Penelitian, Ghalia Indonesia, Jakarta. 
Joharmawan,Ridwan.

2006.

Pengalaman Lesson Study di

Malang. Makalah Pelatihan

Lesson Study untuk

Meningkatkan Kompetensi

Guru Berprestasi dan Pengurus

MGMP Bidang MIPA dan

Bidang Study Lainnya Jenjang

SMP/MTs dan SMA/MA

Wilayah Indonesia Timur.

Rahayu, Sri. 2005. Lesson Study

Sebagai Model Pengembangan

Profesi Guru dalam Upaya

Meningkatkan Pembelajarn

MIPA. Makalah disampaikan

dalam seminar dan workshop

Lesson Study di FMIPA UM,

21 Juni 2005

Richardson, J. 2004. Lesson Study.

Teacher Learn How to Improve

Instruction. National Staff

Development Council (NSDC).

Sudrajat, Ahmad. 2008. Lesson Study

Untuk

Meningkatkan

Pembelajaran.(

on

line).http://www. World

Press.Com.Diakses 31 Mei

2015 